\title{
A WEB BASED SERVICE APPLICATION FOR VISUAL SINKHOLE INVENTORY INFORMATION SYSTEM; CASE STUDY OF KONYA CLOSED BASIN
}

\author{
1Osman ORHAN, ${ }^{2}$ Murat YAKAR, 30sman Sami KIRTILOGLU \\ 1,2,3 Selcuk University, Department of Geomatics Engineering, Campus, Selcuklu, Konya, TURKEY \\ 1'osmanorhan44@gmail.com, 2yakar@selcuk.edu.tr, 3okirtiloglu@selcuk.edu.tr
}

(Geliş/Received: 06.10.2016; Kabul/Accepted in Revised Form: 07.12.2016)

\begin{abstract}
Sinkholes are commonly defined as deep pits giving the appearance of a chimney or well resulting by collapsing of underground rivers in horizontal or near-bedded lime stones or active cave ceilings. Sinkholes appear as deep pits in the so-called karst land, usually on limestones and carbonates that are easily rinsed with water. The sinkhole occurrences in our country are very often seen on the Obruk Plateau in the Konya Closed Basin. In Karapinar region and its surroundings located in this plateau, especially in recent years surface deformations and sinkhole formations are frequent. The resulting sinkholes in the field of agriculture and occurred in areas close to residential areas is to upset the locals.

Several studies have been carried out about the formation of sinkholes in Konya Closed Basin and especially around Karapinar. As a result of the literature survey, different information about the number of sinkholes in the region has been reached. Therefore, an inventory information system that is as up-todate as daily, accurate, and rich in attribute information (position information, shape, diameter, depth, distance to settlements, year of formation, region etc.), has been created as a result of detailed field work, analyzing satellite images, and examining digital terrain model. The inventory information of the 283 objects created within the scope of the study will be used as support data in the future hazard, risk and planning studies. In addition, the inventory data will be shared through a Web-based system with the relevant people and institutions. The Geoinformation System-like Web application is built using Google Maps and Fusion Tables services for data storage and management, both are free services from Google Inc. The web application's infrastructure includes HTML5, CSS3, JavaScript, Google Maps API V3, and Google Fusion Tables API technologies. Using these technologies, it is possible to create effective map "Mash-Up" applications by adding Google maps to a Web page, where spatial data is stored in Fusion Tables and can be displayed as a layer on Google maps. The sinkhole inventory information system presented with web-based application is handled in detail in this article.
\end{abstract}

Key Words: Karapinar, Sinkhole, Inventory, Google API, Mash-Up

\section{Görsel Obruk Envanter Bilgi Sistemi için Web Tabanlı Servis Uygulaması; Konya Kapalı Havzası Örnek Çalışması}

ÖZ: Obruk, yatay veya yataya yakın tabakalı kireç taşlarında bulunan yeraltı nehirlerinin veya aktif mağara tavanlarının çökmesi sonucu oluşmuş, baca veya kuyu görüntüsü veren derin çukurluklara verilen isimdir. Obruklar karst arazi denilen, genelde suyun kolayca eritebildiği kireçtaşları ve karbonatlar içeren düzlüklerde bulunan derin çukurlar şeklinde görünürler. Ülkemizde obruk oluşumları, Konya Kapalı Havzası'nda yer alan Obruk Platosunda çok sıklıkla görülmektedir. Bu 
platoda yer alan Karapınar ve çevresinde, özellikle son yıllarda sıklıkla yüzey deformasyonları ve obruklar meydana gelmektedir. Oluşan obrukların tarım alanlarında ve yerleşim alanlarına yakın bölgelerde meydana gelmesi bölge halkını tedirgin etmektedir.

Konya Kapalı Havzası ve özellikle Karapınar civarında, obruk oluşumları ile ilgili bazı çalışmalar gerçekleştirilmiştir. Literatür araştırması sonucunda, bölgedeki Obruk sayısı ile ilgili farklı bilgilere ulaşılmıştır. Bu yüzden günümüze kadar güncel, doğru ve öznitelik bilgisi bakımından zengin (konum bilgisi, şekil, çap, derinlik, yerleşim yerlerine mesafe, oluşum yılı, bölgesi, vb. ) bir envanter bilgi sistemi, detaylı arazi çalışması, uydu görüntüleri ve bölgeye ait yüksek çözünürlüklü sayısal arazi modelinin incelenmesi sonucunda oluşturulmuştur. Çalışma kapsamında oluşturulan 283 obruğa ait envanter bilgisi gelecekte gerçekleştirilecek tehlike, risk ve planlama çalışmalarında destek veri olarak kullanılacaktır. Ek olarak, bu envanter verisi ilgili kişi ve kurumlar ile Web tabanlı bir sistem vasıtasıyla paylaşılacaktır. Coğrafi Bilgi Sistemi benzeri Web uygulaması, Google firmasının ücretsiz hizmetleri olan Google Maps ve veri depolama ve yönetimi için oluşturduğu Fusion Tables hizmetleri kullanılarak oluşturulmuştur. Web uygulamasının altyapısı HTML5, CSS3, JavaScript, Google Maps API V3 ve Google Fusion Tables API teknolojilerini içermektedir. Bu teknolojilerin kullanılmasıyla, bir Web sayfası içerisine Google haritaları eklenerek, mekânsal verilerin Fusion Tables içerisinde depolandığı ve Google haritalar üzerinde bir katman olarak görüntülenebildiği etkili harita "Mash-Up" uygulamaları oluşturulması mümkün olmaktadır. Web-tabanlı uygulama ile sunulan obruk envanter bilgi sistemi, bu makalede detaylı olarak ele alınmaktadır.

Anahtar Kelimeler: Karapinar, Obruk, Envanter, Google API, Mash-Up.

\section{INTRODUCTION}

Disaster, largely or entirely occurring naturally, exactly unpredictable, occurring suddenly, causing loss of life and property, is defined as a result of climatic events, biological, meteorological, hydrological, and geological origin (Sipahioğlu, 2003; Hoyois et al., 2006; Akıncı et al., 2010).

In recent years, damage reduction studies done in order to minimize the effects of disasters are one of the most studied topics and funded. Now adays, "Risk Identification" and "planning" concepts are the basis of the damage reduction (Safeland, 2010; Bilgilioğlu, 2014; Ozturk, 2016). Determination of disaster risk areas and preparation of their plans depend on the existing accurate and timely inventory information, which exist, about disasters. In this context, essential spatial information must be determined for disasters such as sinkholes, earthquakes, landslides, floods etc. in risk assessment and planning studies. This information must be collected and presented to the stakeholders in a GIS environment at immediately or soon after the disaster.

The formation of sinkholes, which is one of the types of geological disasters, involves natural processes of erosion or gradual removal of slightly soluble bedrock (such as limestone) by percolating water, the collapse of a cave roof, or a lowering of the water table. Sinkholes often form through the process of suffusion. For example, groundwater may dissolve the carbonate cement holding the sandstone particles together and then carry away the lax particles, gradually forming a void (Friend, 2002). Sinkhole formations are very often seen in the Obruk Plateau located in Konya Closed Basin in our country.

Sinkhole formation is a natural disaster that occurred as a result of land use and excessive groundwater usage. Sinkhole formations usually seen in Konya Closed Basin (KCB) in general (Ustun et al., 2010). The majority of sinkholes are to be found in Karapinar located in KCB. In recent years, sinkholes, which create space under soluble limestone in time and formed by the collapse of the ground, has created large negative effects on socio-economic development of the region and damaged the cultivated area. Also, it has become a threat for residential area and folk's safety. 
Over the past two decades, developments in Internet and technology have brought the concept of Web-mapping. Web mapping is the process of implementing and visualizing maps on the World Wide Web (WWW or commonly just Web). Since the birth of the Web in 1989 (Tim Berners-Lee, 2016), invented at CERN for the exchange of research documents and shortly after the emergence of the first map server Xerox PARC Map Viewer (Putz, 1994), Web-based maps (or Web maps) have raised widespread use and have evolved to Rich Internet Applications (RIA) at the present. Web maps are often used to display overlays to bring information to users via the Internet. These overlays may contain information from other Web sources (i.e. RSS feeds) and/or users own external data. Getting an overlay onto a Web map varies depending upon the mapping API (Application Programming Interface). In computer programming, an application programming interface (API) is a set of routines, protocols, and tools for building software and applications (Wikipedia, 2016). An API may be for a Web-based system, operating system, or database system, and it provides facilities to develop applications for that system using a given programming language. Of course the way of delivering Web maps substantially changed in 2005 when Google introduced its tile-based mapping system based on AJAX that facilitated interactive zooming and panning (Peterson, 2012). Just 6 months after the release of the Google Maps, Google has launched Google Maps API which makes it possible to embed a Google Map on any Website or Web page free of charge and provides overlaying information from other Web sources or users own external data. Other online map providers like Microsoft Bing Map, MapQuest, Yahoo! Maps, OpenStreetMap and ESRI include an API. Almost all of these services support adding geometric primitives like point (marker), polyline and polygons as an overlay and creating info windows, putting image overlays on top of the map and external data layer support for common types as KML, JSON or GeoRSS. Some providers like Google, also have advanced tools such as Fusion Tables for data storage, management and overlay as a layer on the map.

There are a lot of alternatives to create a Web map that fulfills basic mapping functions and almost all of these are free of charge except some usage limits. Even the majority of them allow creating powerful heatmaps automatically.

Therefore, the aims of this study are the creation a sinkhole inventory information system, which shows their spatial distributions, features and relationship between environmental factors, and to make reachable these information systems for people on the subject with the help of a visual Web-based service application for sinkhole inventory system for Konya Closed Basin.

\section{MATERIAL AND METHOD}

\section{Study Region}

The KCB is located in the Central Anatolian Plateau (Turkey) at latitude $36^{0} 51^{\prime}-39^{\circ} 29^{\prime} \mathrm{N}$ and longitude $31^{\circ} 36^{\prime}-34^{\circ} 52^{\prime} \mathrm{E}$ and at an altitude of about 1,000 m (Figure 1). KCB covers a 5,426,480-ha surface area (nearly $7 \%$ of Turkey's total area) larger than that of The Netherlands. Within the basin, there are 11 watery regions (lakes, reed beds) named as Lakes Samsam, Kozanl, Kulu, Beyşehir, Suğla, Bolluk, Tersakan, Tuz and Reed Beds Ereğli, Reed Bed and Hotamış. A smooth plane at 900-1,050 m altitude has formed the main part of the Central Anatolia Plateau in KCB, Turkey's largest closed basin in which three million people live, $45 \%$ in rural areas and $55 \%$ in urban areas. The a gricultural revenue provided by $\mathrm{KCB}$ was due to grains $(9.2 \%)$, beans $(6.2 \%)$, and industrial crops including sugar beet $(8.5 \%)$. As a result of insufficient drainage, the soils of the region usually have the alluvial and salty characteristics due to high groundw ater level, watering, and terrestrial semiarid mild climate conditions dominant in the basin. The water of the basin comes to an end in stagnant water, marshy places, or semimarshy places. The lack of a river in this wide basin, limited rainfall, and high evaporation ratios have formed a favorable water balance that is rarely met in closed basins. The shallow lake and reed beds at the center of the basin are fed by many rivers flowing to the region. The climate characteristics of the basin present the Mediterranean climate (mild and rainy winters, hot and dry summers) at the south, 
the terrestrial climate (cold winters, hot and dry summers) at the center and north of the basin, and the desert climate in Karapinar and its vicinity. The rainfalls were mostly observed in winter and spring seasons. The natural richness and the lakes of the basin provide significant living places for the migratory birds (Durduran, 2010; Doğdu et al., 2007). In scope of this study, boundary of Konya Closed Basin has been selected as a study area in general. However, more studies have been carried out in Karapınar having more sinkholes formation.

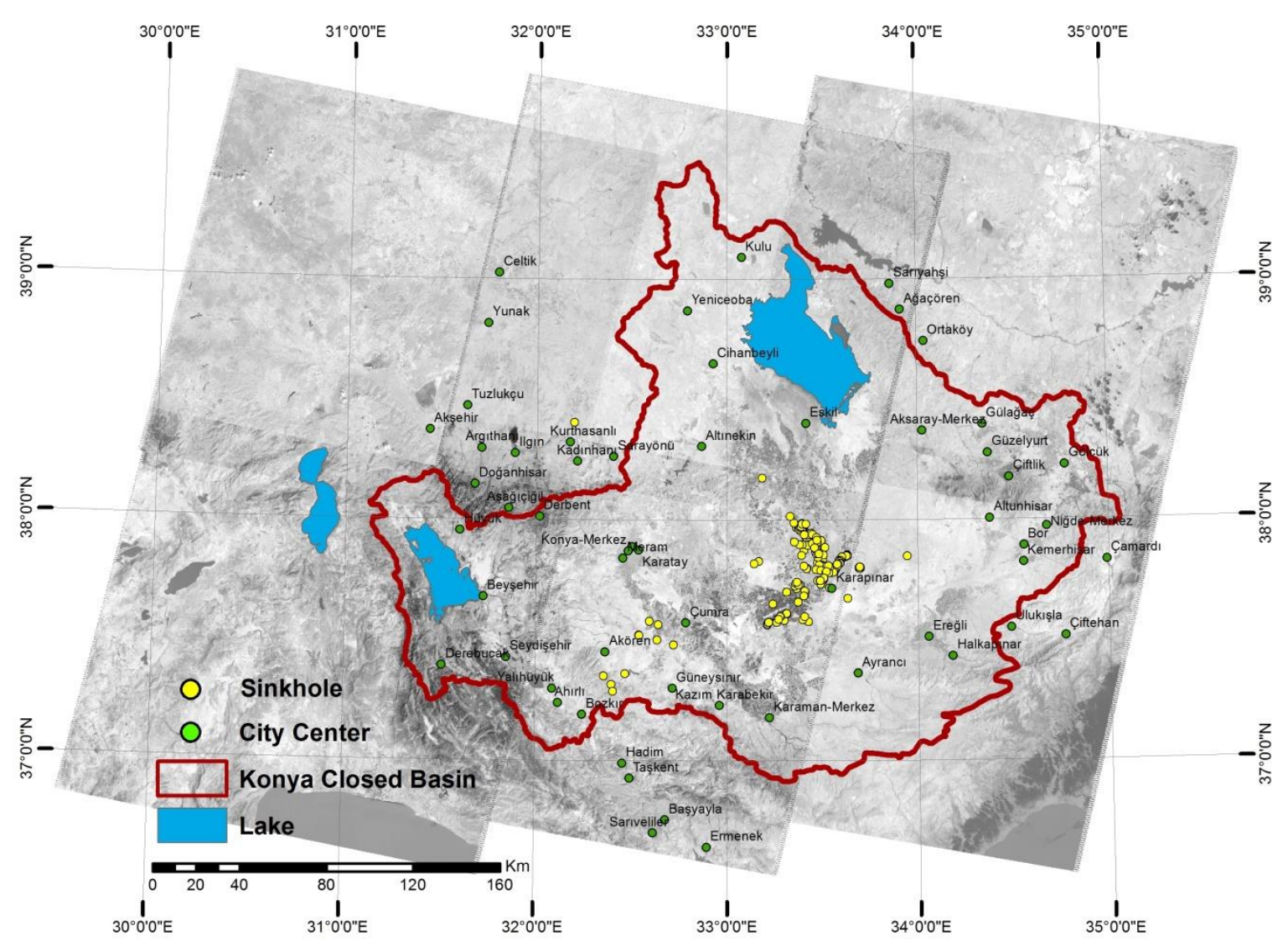

Figure 1. Study Area

\section{Fieldwork}

Fieldw ork was conducted in Karapinar and its surroundings. First of all, a comprehensive literature review was performed without doing field work. Information about some sinkholes in Karapinar, was collected from previous studies carried out in this area. 


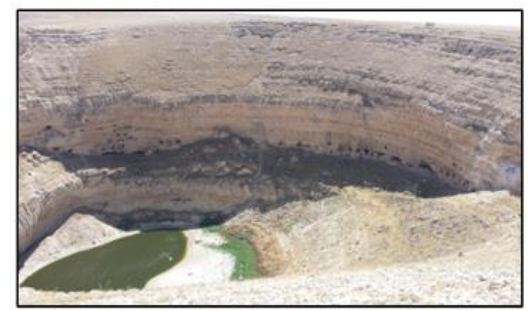

(a) Çıralı Sinkhole

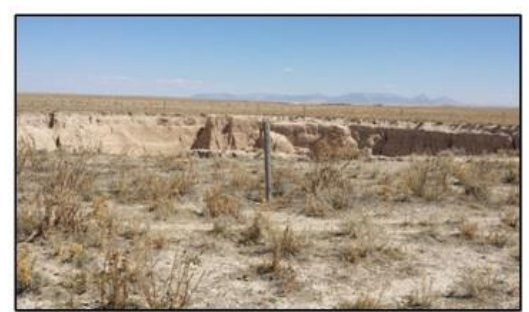

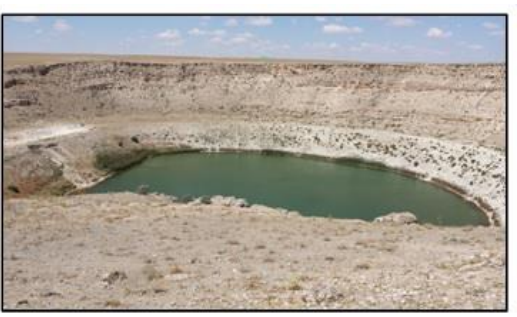

(b) Meyil (Eğimli) Sinkhole

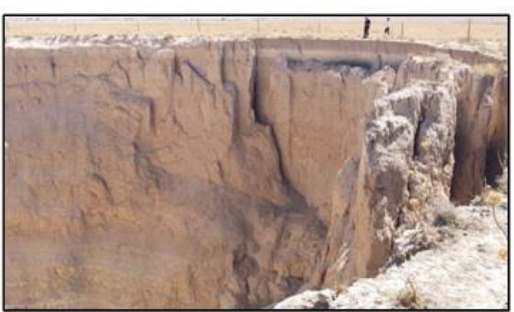

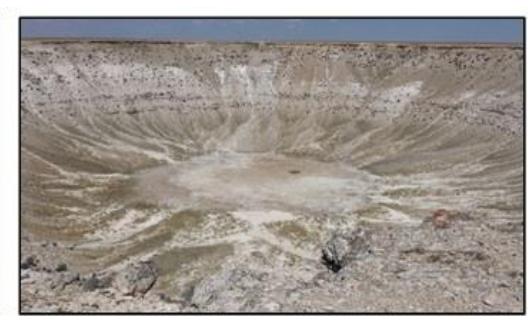

(c) Osmanoğlu Sinkhole

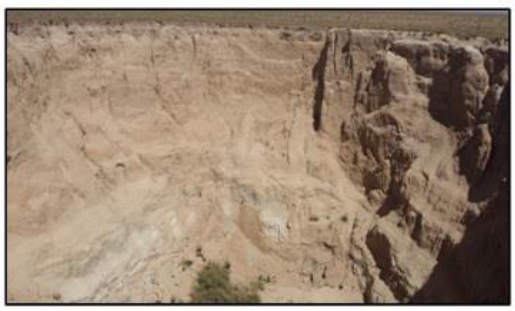

(d) A new ly formed sinkhole In the spring of 2015 (Diameter $80 \mathrm{~m}$, depth $60 \mathrm{~m}$ )
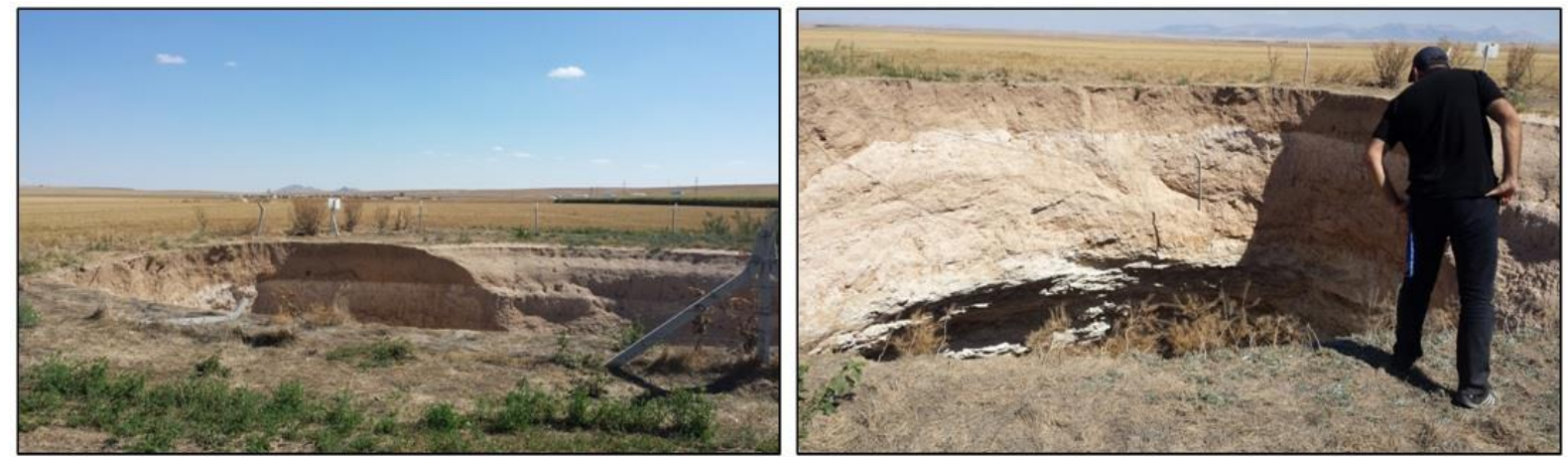

(e) A new sinkhole formed in the region close to settlements in the spring of 2015 (Diameter $60 \mathrm{~m}$, depth $70 \mathrm{~m}$ )
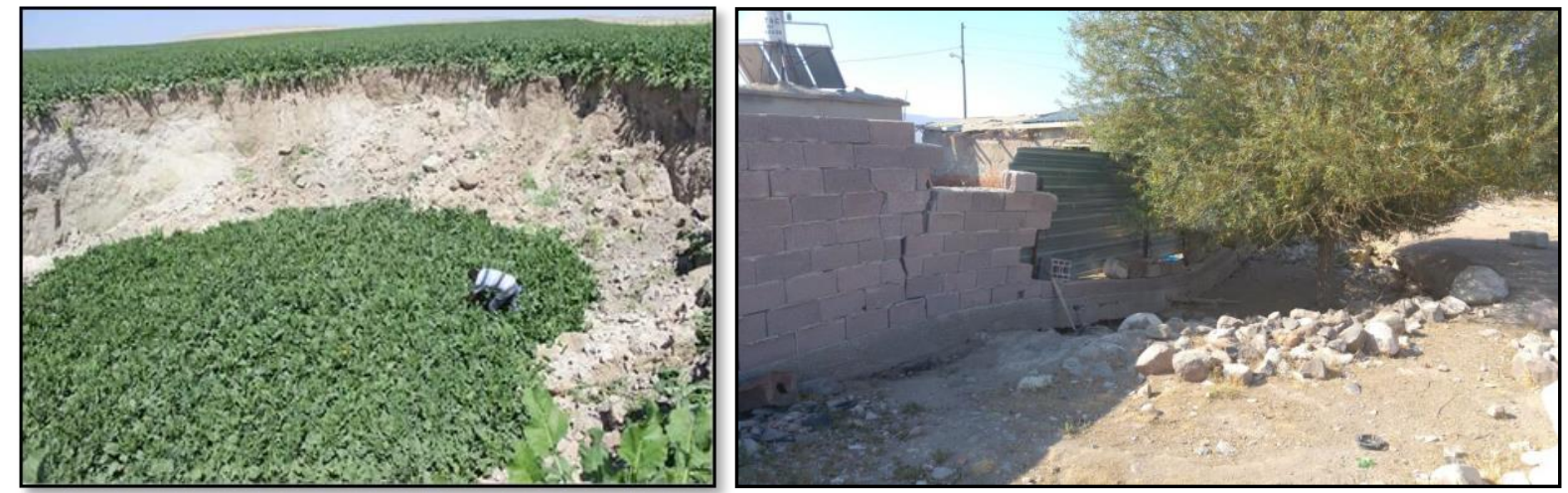

(f) A sinkhole formed in the beet field on 23 Aug 2016

(g) A sinkhole in the settlement in Nasuhpinar region
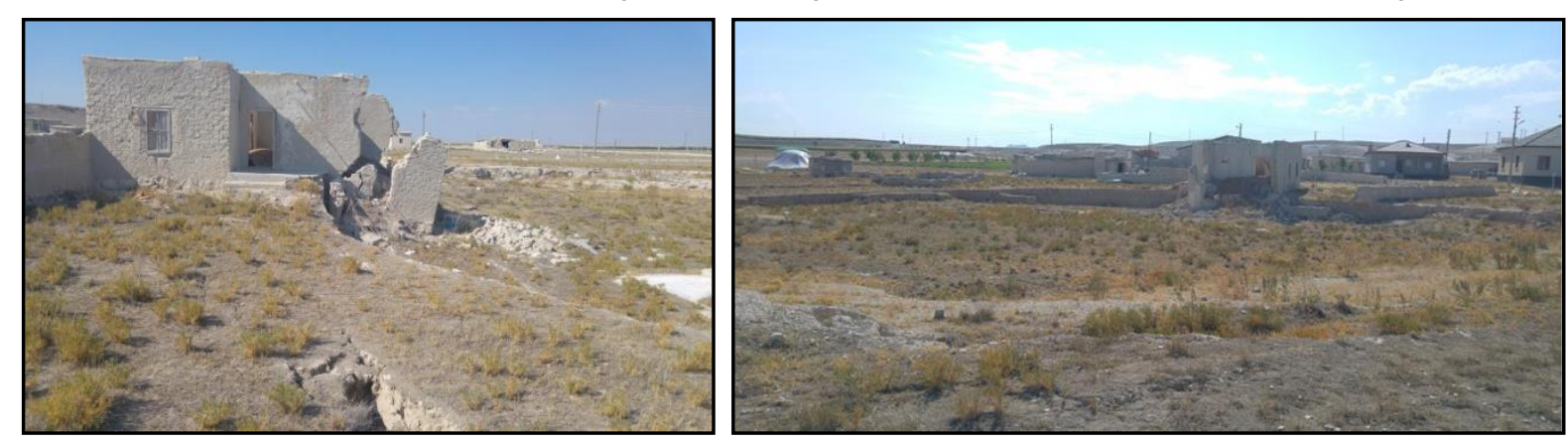

(h) A new sinkhole formed within the settlement in 2014 (Diameter: $50 \mathrm{~m}$ )

Figure 2. Images from field work in Karapınar and its surroundings 
As a result of the literature review, the spatial and attribute information about around 100 sinkholes, was obtained (Bozyigit and Tapur, 2009; Yllmaz, 2010; Dogan and Y1lmaz, 2011; Bozyigit and Tapur, 2013). High-resolution satellite images and aerial photography were used in the determination of the other sinkholes in this area.

Sinkhole locations and potential sinkhole locations have been marked by examining satellite images and aerial photography. Moreover, sinkhole locations easily determined by using the Digital Elevation Model (DEM) which were produced using images of Cosmo-SkyMed satellite data. Before starting the fieldwork, 398 point was determined using DEM, satellite images and aerial photography. Later, Fieldwork carried out with GPS, Total Station etc. in order to determine whether these specified points are sinkholes and to collect geometric and attribute information in Karapinar and its surroundings. Sinkhole No, Sinkhole Name, Town, Region, Year, Distance from Residential Area, Sinkhole Shape, Sinkhole Depth, , Sinkhole Diameter, Elevation, Groundwater Stiation, Information, Lat-Long have been collected for each sinkholes as a result of both filedwork and interviews with the people. 283 Sinkholes were found as a result of this fieldw ork.

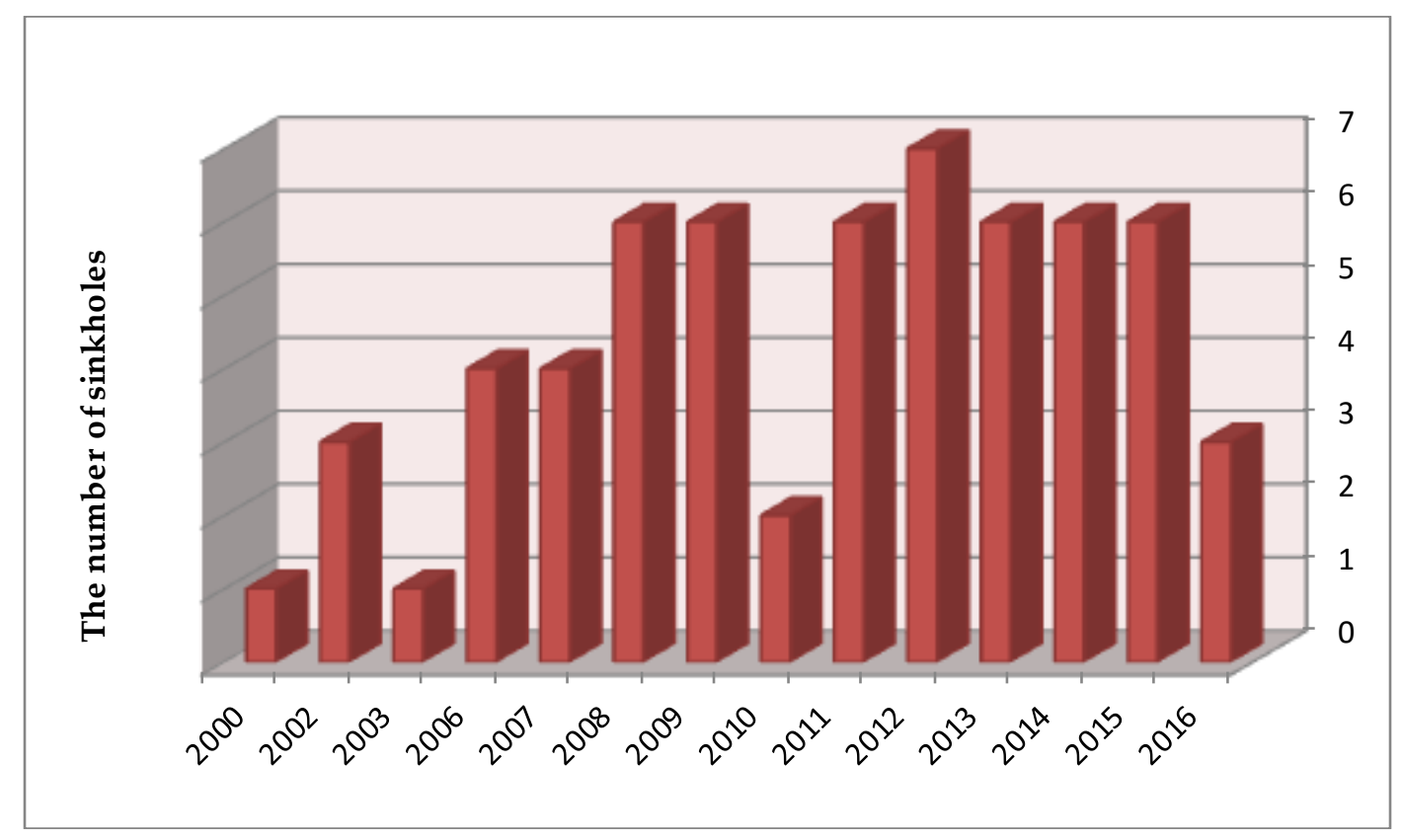

Figure 3. The number of sinkholes formed between 2000 and 2016

After the field work in Karapinar and its surrounding area, it has been determined that from the year 2000 until today, 61 sinkholes were formed. Figure 3 shows that sinkholes regularly have formed every year since 2000 and An average of 6 sinkholes formed for each year in the last six year. Mor over, it is observed that sinkholes, formed in the region of Karapinar, are located in the settlement area and its surrounding.

\section{Web-Based Application}

For the purpose of visualizing and sharing the results, a Web based application has been established by using Google Maps and its useful data storage and manipulating product Fusion Tables which are all Google's free of charge Web service elements. The infrastructure of Web application includes HTML5, CSS3, JavaScript, Google Maps API V3 and Google Fusion Tables API technologies. These technologies make it possible to make effective Web-based applications involving an embedded Google Map in a Web page, storing the spatial or tabular data in Fusion Tables and add this data as a map layer on embedded map. A useful option with Google Maps is the support of using Fusion Tables as layers on 
the map application. Google Fusion Tables is a cloud-based service for data management and integration. Fusion Tables enables users to upload tabular data files (spreadsheets, CSV, KML), currently up to $100 \mathrm{MB}$. The system provides several ways of visualizing the data (i.e., charts, maps, and timelines) and the ability to filter and aggregate the data. It supports the integration of data from multiple sources by performing joins across tables that may belong to different users. Users can keep the data private, share it with a select set of collaborators, or make it public and thus crawlable by sear ch engines.

The service launched in June 2009. By the Fusion Tables API, users can copy a small fragment of JavaScript code into the source of their page (e.g., a blog entry) and the visualization will be displayed there, with a live link to the data. That is, when the data is updated in Fusion Tables, the visualization is also updated (Gonzales et al., 2010). It provides client-side visualizations through the Google Visualization API. This is a well-established framework for visualizing data on the client. The visualization is rendered on the browser using JavaScript or Flash, and the data required by the visualization is obtained from a data source interface. The sinkhole attribute files were produced as KML (Keyhole Markup Language) files and added on the map as Fusion Tables layers. Also the sinkhole images were produced as raster image files and added on each sinkhole attribute and their infowindow. Fusion Tables are also have the ability of heatmap function. Heatmaps display colors on the map to represent the density of points from a table. Figure 4 illustrates the distribution of sinkhole point locations.

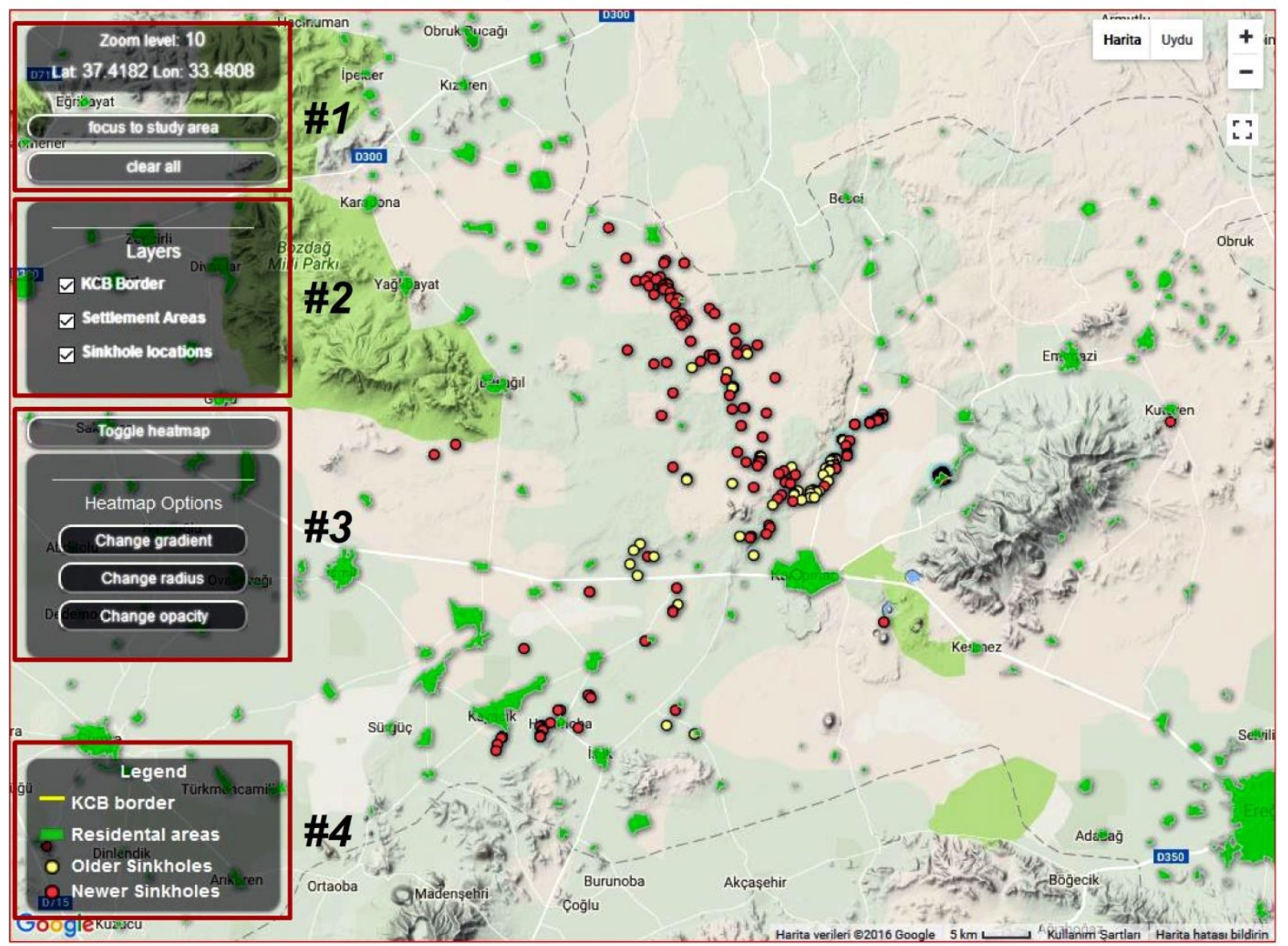

Figure 4. Distribution of sinkholes as point locations 
In figure 4, focus to study area button, to clear all layer button, coordinate and zoom level information is cantained in box 1 , buttons to open and close the layers is cantained in box 2, toogle heatmap screen located in box 3 located in figure 4, and legend located in box 4 . Figure 5 illustrates heatmap display of same points. Moreover, heatmap buttons provide three different display option such as; change gradient, change radius, change opacity.

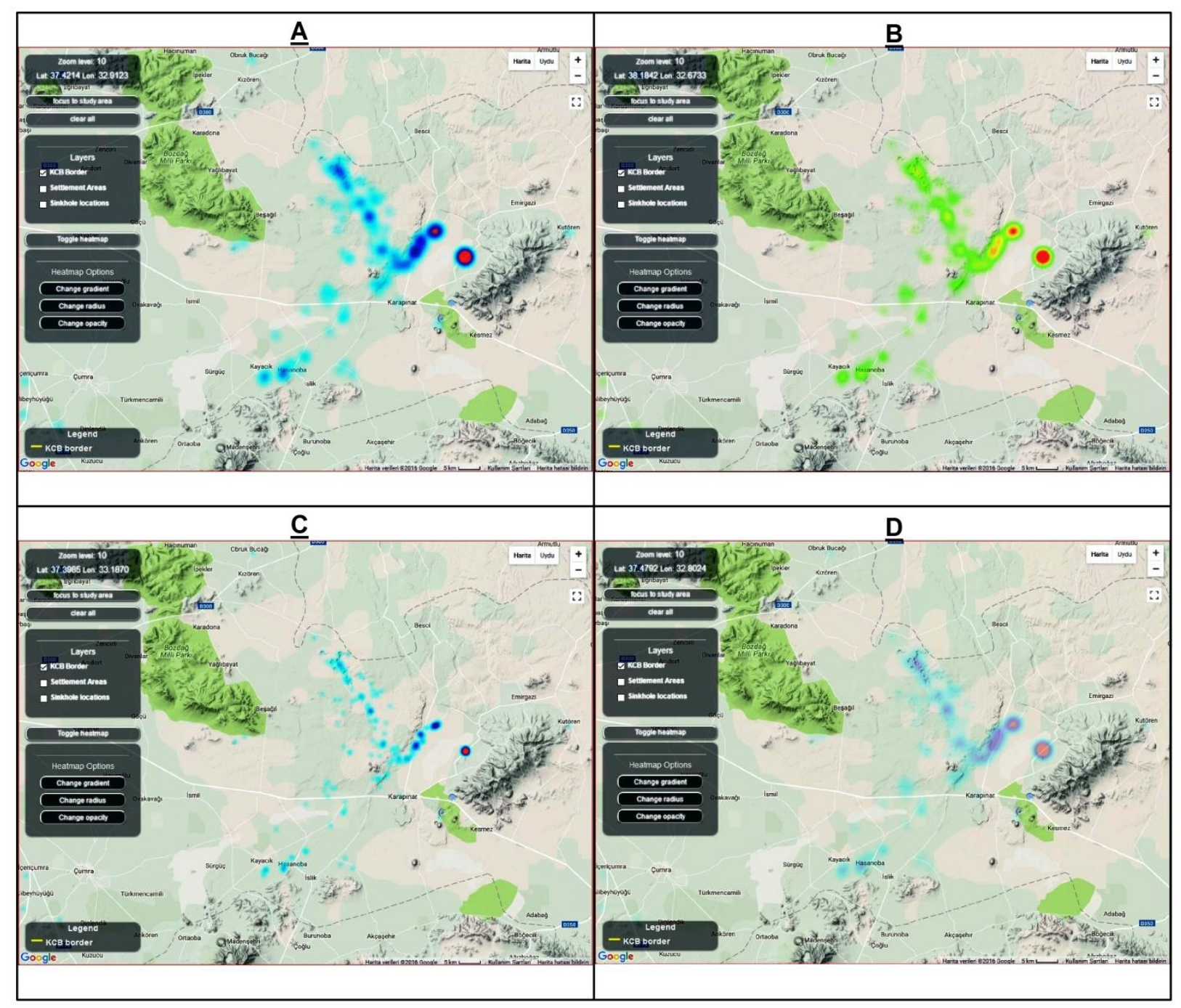

Figure 5. A: Heatmap display of sinkholes; B: Effect of the change gradient for heatmap; C: Effect of the change radius for heatmap; D: Effect of the change opacity for heatmap

The main idea of produced Web-based application is to display the determined sinkhole locations as points in an interactive Web-based map and provide attributes of sinkholes to users as infowindows. It comes from the idea of simplest way to keeping up to date information and sharing with concerned clients. Figure 6 shows an infow indow of a sinkhole when clicked on the map. 


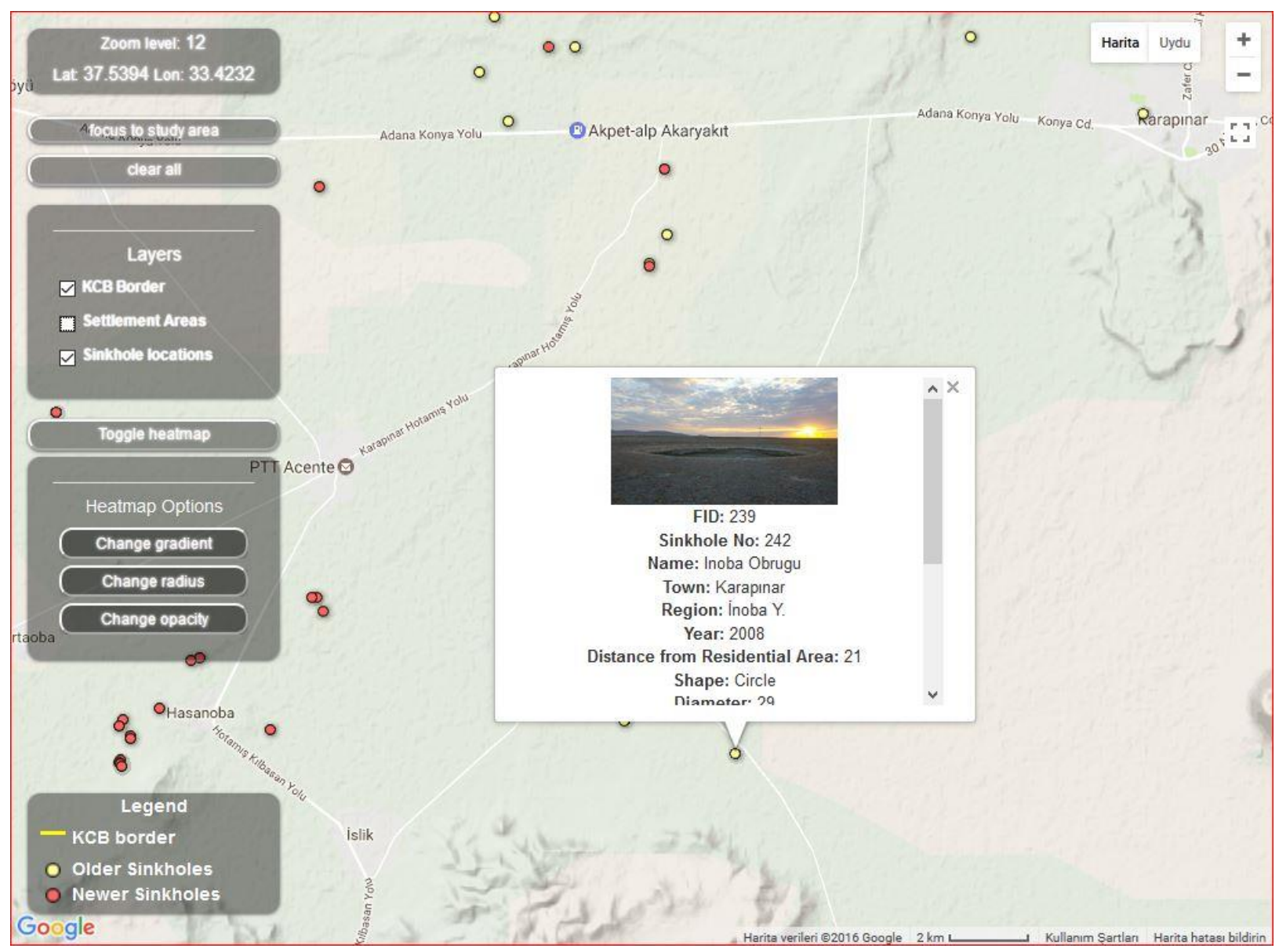

Figure 6. An infowindow of a sinkhole

\section{CONCLUSION}

In this study, it was studied to complete for the inventory data of sinkhole one of the most important problems in Konya closed basin and sinkhole inventory information (geometric and attribute information), one of the base needed of disaster management, has been completed In order to reduce the effects of this disaster. One of the base maps was prepared to demonstrate the profiles of the disaster in this region with disaster databases kept the inventory data.

283 sinkholes have been identified by examining satellite images, aerial photography and interviews with the people living in this study area in Karapinar and its surroundings in scope of the creation of sinkholes inventory information system. Three sinkholes (64/15/25m in diameter and 30/ 0.6/ $6 \mathrm{~m}$ in depth) formed in this region until august 2016. As a result of literature research and interviews with the people living there 61 of 283 sinkholes have occurred in this area since 2000. 21 of 283 sinkholes were filled in order to prevent the decline in estate values and continue the agricultural activity.

Sinkhole inventory maps are the basis of the input parameters of regional scale sinkhole susceptibility, potential hazards and risks assessments. Appropriate use of produced Sinkhole inventory maps is expected to create a favorable impact in sinkhole risk management and mitigation activities in Konya Closed Basin.

A Web-based application produced to provide interactive maps for delivering sinkhole information to concerned clients which uses Google Maps infrastructure. We used Google Fusion Tables to store, manage and manipulate data, because it is free (except some limitations), easy to create interactive maps and share via a link or embed your own Web page, and easy to keep up to date. Our application is a Web page including an embedded Google Map window and a Fusion Table layer on this map. As a 
future work, we are planning to improve this application as a GIS (Geographic Information System) like environment which clients are capable of performing spatial queries or permitted ones can edit the database.

\section{REFERENCES}

Akıncı H., Doğan S., Kılıçoğlu C., Keçeci S. B., 2010, "Production of The Landslide Susceptibility Map of Samsun City Center", Electronic Journal of Map Technologies, Vol. 2(3), pp. 13-27. (in Turkish)

Berners-Lee, T., 2016, Frequently Asked Questions-Start of the Web. https://www.w3.org/People/Berners-Lee/FAQ.html [26.04.2016]

Bilgilioğlu, S., 2014, Developing Geographic Data Model To Create Landslide Maps And Its Use In Disaster Management, Master Thesis, Aksaray University, Graduate School of Natural and Applied Sciences, Aksaray.

Bozyiğit, R., Tapur, T., 2013, Sinkhole Invebtory for Konya. 8 th.Regional Directorate of Nature Conservation and National Parks, Konya Branch Directorate Project.

Bozyiğit, R., Tapur, T., 2009, "The Effect of Ground Waters for Formation of Obruk in Konya Plain and Around", Selçuk University Journal of Social Sciences Institute, Vol. 21, pp. 137-155.

Doğan, U., Yılmaz, M., 2011, "Natural and Induced Sinkholes of The Obruk Plateau and KarapinarHotamış Plain, Turkey" Journal of Asian Earth Sciences, Vol. 40(2), 20 January 2011, pp. 496-508, ISSN 1367-9120,

Doğdu, M. S., M. M. Toklu, C., Sağnak, 2007, “Examination of Precipitation and Groundwater Level Values in Konya Closed Basin", First Turkish Climate Change Congress, (in Turkish), pp. 394401.11-12 April 2007, İstanbul.

Durduran, S. S., 2010, "Coastline Change Assessment on Water Reservoirs Located in The Konya Basin Area, Turkey, Using Multitemporal Landsat Imagery". Environmental Monitoring and Assessment, Vol. 164, pp. 453-461.

Friend, S., 2002, Sinkholes. Pineapple Press Inc. p. 11. ISBN 1-56164-258-4. Retrieved 7 June 2010, USA.

Gonzalez, H., Halevy, A., Jensen, C.S., Langen, A., Madhavan, J., Shapley, R., Shen, W., “Google Fusion Tables: Data Management, Integration and Collaboration in The Cloud". In Proceedings of the 1st ACM Symposium on Cloud Computing (pp. 175-180). 10 - 11 June 2010, Indianapolis, IN, USA

Hoyois, ,P., Below, R., Scheuren, J-M., Guha-Sapir, D., 2006. Annual Disaster Statistical Rewiew Numbers And Trend, Univeriste Catholique De Louvain-Brussels-Belgium, Brussels.

Öztürk, O., 2016, Developing Geographic Data Model to Create Landslide Hazard Maps and Its Use in Disaster Management, Master Thesis, Aksaray University, Graduate School of Natural and Applied Sciences, Aksaray.

Peterson, M. P., 2012, Online Mapping With APIs, In: Online Maps with APIs and WebServices, Eds: Springer, pp. 3-12.

Putz, S., 1994, "Interactive Information Services Using World-Wide Web hypertext", Computer Networks and ISDN Systems, Vol. 27 (2), pp. 273-280.

Safeland, 2010, Living With Landslide Risk in Europe: Assessment, Effects of Global Change, and Risk Management Strategies, Grant Agreement Project No. 226479, 7th Framew ork Programme of the European Commission.

Sipahioğlu, Ş., 2003, Location and Evaluation of Natural Disasters in Geography Curriculum., s.96-101. Ankara: Gazi Publications.

Ustun, A., Tusat, E., \& Yalvac, S., 2010, “Preliminary Results of Land Subsidence Monitoring Project in Konya Closed Basin Between 2006-2009 by Means of GNSS observations", Natural Hazards and Earth System Sciences, Vol. 10(6), pp. 1151-1157.

Wikipedia Contrubitors, 2016, The Definition of Application Programming Interface, https://en.wikipedia.org/wiki/Application_programming_interface [26.04.2016] 
Yılmaz, M., 2010, "Environmental Problems Caused by Ground Water Level Changes around Karapinar", Ankara University Journal of Environmental Sciences, Vol. 2(2), pp. 145-163. 